\title{
UJI FUNGSI PARU PADA ANAK SEKOLAH DASAR DI WILAYAH PABRIK BATU KAPUR DI DESA GARAWANGI KABUPATEN MAJALENGKA
}

\author{
Lili Mulyatna*, Yonik Meilawati Yustiani, Happy Dhamayantris \\ Program Studi Teknik Lingkungan, Universitas Pasundan
}

\begin{abstract}
Abstrak
Fungsi paru-paru manusia dapat menurun karena terpapar debu. Gangguan fungsi paru-paru umumnya terjadi karena adanya faktor individu dan faktor lingkungan. Penelitian ini dilakukan untuk mengetahui kondisi paru-paru anak di daerah sekitar pabrik batu kapur. Alat yang digunakan dalam penelitian ini adalah Peak Flow Meter sebagai pengukur uji fungsi paru. Selain itu dilakukan pulan pengukuran tinggi badan dan usia anak. Sebagai responden adalah murid-murid Sekolah Dasar Garawangi II, yang bertujuan mengetahui kondisi dan mengetahui faktor-faktor yang terkait dengan fungsi paru di sekitar pabrik batu kapur. Jumlah responden adalah 226 siswa. Berdasarkan hasil penelitian, dari 226 responden, 14 anak tidak sesuai sebagai responden, 100 (47\%) anak yang memiliki kondisi paru-paru normal dan 112 (53\%) anak didiagnosis dengan gangguan fungsi paru. Faktor yang terkait dengan hasil ini adalah usia, tinggi dan jenis kelamin. Terdapat faktor lain yang juga diteliti namun secara statistik tidak terhubung yaitu menjadi perokok pasif dan jarak rumah di dekat pabrik.
\end{abstract}

Kata kunci: Nilai Arus Puncak Ekspirasi, Uji Fungsi Paru

\section{Pendahuluan}

Udara bersih ialah udara yang belum tercampur dengan gas-gas yang berbahaya. Ciri-ciri bersih yaitu: tidak berwarna, tidak berbau, terasa egar dan ringan saat di hirup. Sedangkan udara kotor adalah yang sudah terpapar atau tercampur dengan gas-gas yang berbahaya. Ciri-cirinya yaitu: berbau dan berwarna seperti yang terlihat di kendaraan bermotor atau cerobong pabrik.

Pembangunan yang berwawasan lingkungan telah diterima sebagai suatu prinsip Pembangunan Nasional yang bertujuan untuk memperbaiki taraf hidup masyarakat dengan berbagai peraturan pelaksanaannya. Namun, dalam pelaksanaan di lapangannya peraturan

\footnotetext{
${ }^{*}$ Penulis Korespondensi:

E-mail: lili.mulyatna@gmail.com

Diterima pertama kali: 8 Maret 2017

Direvisi : 23 Juni 2017

Disetujui untuk publikasi: 30 Juli 2017
}

yang telah ditetapkan belum berjalan sebagaimana yang diharapkan. Dewasa ini banyak berita tentang pencemaran udara yag sering di jumpai di media massa yang ditimbulkan oleh kegiatan manusia. Dengan di berlakukannya Undang-Undang nomor 23 Tahun 1997 tentang Pengelolaan Lingkungan Hidup dan Undang-Undang nomor 32 Tahun 2004 tentang Pemerintahan Daerah, maka pengelolaan lingkungan hidup menjadi salah satu kewenangan yang diserahkan kepada pemerintah daerah, seperti yang terjadi di Desa Garawangi Kecamatan Sumberjaya Kabupaten Majalengka.

Kegiatan pengolahan batu gamping atau batu kapur di Desa Garawangi mempunyai dampak yang positif dan negarif kepada kesehatan masyarakat dan lingkungan sekitar. Kegiatan ini satu pihak akan memberikan keuntungan berupa memberikan lapangan pekerjaan, mempermudah 
komunikasi dan transportasi serta akhirnya meningkatkan ekonomi dan sosial masyarakat (Rachmawati, M.Masykuri, \& Sunarto, 2013).

Sisi lainnya dapat timbulnya dampak negatif karena paparan zat-zat yang dapat dari proses pengolahan batu kapur tersebut. Apabila tidak mendapatkan penanganan yang baik maka tidak menutup kemungkinan akan berpengaruh terhadap kesehatan masyarakat dan kelestarian lingkungan sekitar (Idrus, 2013). Salah satu dampak negatifnya adalah penurunan kualitas lingkungan yang ditandai adanya pencemaran udara. Yang menjadi latar belakang penelitian ini adalah untuk mengetahui pengaruh dari debu batu kapur terhadap nilai arus puncak ekspirasi paru anak-anak Sekolah Dasar (SD) dengan menggunakan alat peak flow meter, yang berlokasi di Desa Garawangi Kecamatan Sumberjaya Kabupaten Majalengka.

Kandungan debu kapur yang bisa mengganggu kesehatan paru-paru anak-anak Sekolah Dasar yang sekolahnya dekat dengan lokasi pencemaran. Untuk mendapatkan gambaran awal tentang adanya hubungan antara pencemaran udara dari pabrik batu kapur dengan nilai arus puncak ekspirasi (APE) anak usia sekolah, maka penelitian ini perlu dilakukan.

Tujuan penelitian ini untuk mengidentifikasi dan mendapatkan suatu hasil berupa nilai arus puncak ekspirasi (APE) anak usia 6-13 tahun di SD Negeri Garawangi II yang merupakan wilayah pabrik batu kapur.

\section{Metodologi Kajian}

\section{Lokasi Penelitian}

Lokasi yang akan dijadikan penelitian ini yaitu di SD Negeri Garawangi II yang berlokasi di Desa Garawangi Kecamatan Sumberjaya Kabupaten Majalengka. Waktu Pelaksanaan bulan oktober 2015 dengan jumlah responden 226 orang.

Alat yang digunakan pada saat melakukan penelitian
Peak Flow Meter (PFM) adalah alat untuk mengukur jumlah aliran udara dalam jalan napas (PFR) (Adeniyi \& Erhabor, 2011). Nilai PFR dapat dipengaruhi beberapa faktor misalnya posisi tubuh, usia, kekuatan otot pernapasan, tinggi badan dan jenis kelamin. Peak Flow Meter (PFM) adalah alat ukur kecil, dapat digenggam, digunakan untuk memonitor kemampuan untuk menggerakkan udara, dengan menghitung aliran udara bronki dan sekarang digunakan untuk mengetahui adanya obtruksi jalan napas.

Ada beberapa langkah dalam pemeriksaan arus puncak ekspirasi:

1. Bila memerlukan, pasang mouthpiece ke ujung peak flow meter

2. Penderita berdiri atau duduk dengan punggung tegak dan pegang peak flow meter dengan posisi horisontal (mendatar) tanpa menyentuh atau mengganggu gerakan marker. Pastikan marker berada pada posisi skala terendah (nol).

3. Penderita menghirup napas sedalam mungkin, masukkan mouthpiece ke mulut dengan bibir menutup rapat mengelilingi mouthpiece, dan buang napas sesegera dan sekuat mungkin. Dengan ilustrasi pada gambar seperti meniup deretan lilin secara kuat dalam satu tiupan.

4. Saat membuang napas, marker bergerak dan menunjukkan angka pada skala, catat hasilnya.

5. Kembalikan marker pada posisi nol lalu ulangi langkah 2-4 sebanyak 3 kali, dan pilih nilai paling tinggi. Bandingkan dengan nilai terbaik pasien tersebut atau nilai prediksi.

6. Pada penderita anak, langkah 3 seolah-olah seperti meniup lilin ulang tahun. 


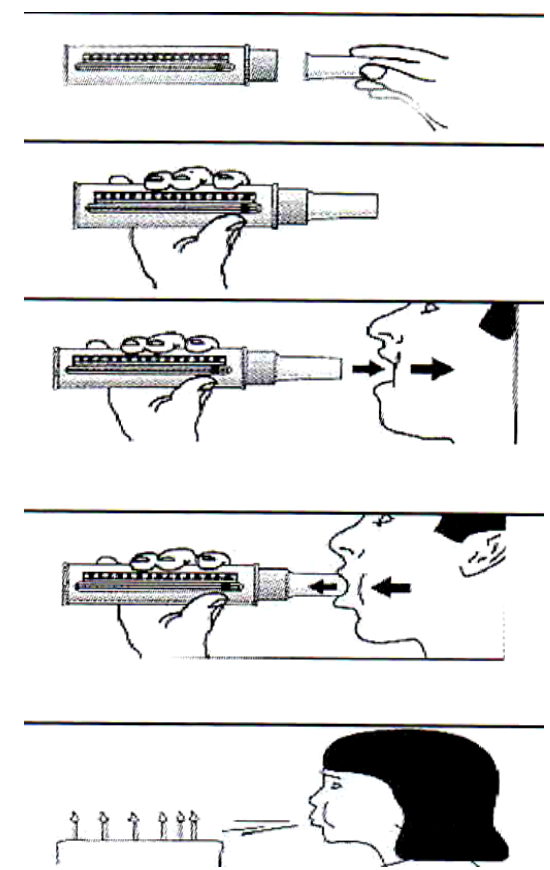

Gambar 1. Cara Menggunakan Alat Peak Flow Meter

\section{Metode Pengolahan Data Penelitian}

Data penelitian berupa nilai arus puncak ekspirasi anak-anak yang sudah diambil dengan alat Peak Flow Meter dengan data pendukung seperti umur, tinggi badan dan jenis kelamin di sekolah yang menjadi lokasi penelitian tersebut kemudian dihitung nilai prediksi PEFR dengan rumus sebagai berikut (Tim-Pneumobile-Project, 1992):

- Laki-laki: PEFR $(\mathrm{L} / \mathrm{dtk})=-10,86040+$ $0,12766 \times$ Umur $+0,11169 \times \mathrm{TB}-$ $0,0000319344 \times$ Umur $^{3}+1,70935$

- Perempuan: PEFR (L/dtk) $=-5,12502+$ $0,09006 \times$ Umur $+0,06980 \times$ TB $0,00145669 \times$ Umur $^{2}+1,77692$

Keterangan:

- Umur dengan satuan tahun, TB (tinggi badan) dengan satuan $\mathrm{cm}$

- Bila menginginkan hasil dengan satuan L/menit, hasil perhitungan dikali 60
Kemudian setelah didapatkan nilai prediksi PEFR dilanjutkan memproses data penelitian dengan menggunakan rumus sebagai berikut :

Hasil Perhitungan $=$

$$
\frac{\text { nilai tertinggi peak flow }}{(\text { nilai prediksi normal } \times 60)} \times 100 \%
$$

Untuk mendapatkan kondisi paru apakah kondisi paru-paru anak normal yaitu $>80 \%$ dan jika < 80\% maka didiagnosa ada penurunan kondisi paru pada anak yang seang diperiksa.

\section{Hasil dan Pembahasan}

Hasil dari perhitungan nilai arus puncak ekspirasi (APE) dari sekolah yang menjadi objek penelitian, yaitu SD Negeri Garawangi II yang berada di daerah terpapar debu dari pabrik batu kapur di Desa Garawangi Kecamatan Sumberjaya Kabupaten Majalengka.

Berdasarkan penjelasan di atas maka yang menjadi populasi dari penelitian ini adalah seluruh siswa yang berkaitan dengan objek penelitian. Jumlah populasi di SD Negeri Garawangi II 226 orang dengan rincian sebagai berikut:

Tabel 1. Jumlah Populasi di SD Negeri Garawangi II

\begin{tabular}{clc}
\hline No. & Nama Kelas & Jumlah Siswa \\
\hline 1. & Kelas 1 & 30 \\
\hline 2. & Kelas 2 A & 30 \\
\hline 3. & Kelas 2 B & 20 \\
\hline 4. & Kelas 3 & 34 \\
\hline 5. & Kelas 4 A & 21 \\
\hline 6. & Kelas 4 B & 20 \\
\hline 7. & Kelas 5 & 28 \\
\hline 8. & Kelas 6 A & 23 \\
\hline 9. & Kelas 6 B & 20 \\
\hline \multicolumn{2}{c}{ TOTAL : }
\end{tabular}


Tabel 2. Perbandingan nilai fungsi paru dengan umur

\begin{tabular}{|c|c|c|c|}
\hline $\begin{array}{c}\text { Jenis } \\
\text { kelamin }\end{array}$ & Umur & Frekuensi & $\begin{array}{c}\text { Nilai } \\
\text { Rata- } \\
\text { rata }\end{array}$ \\
\hline \multirow{7}{*}{$\mathrm{L}$} & 6 tahun & 5 & 92 \\
\hline & 7 tahun & 21 & 96 \\
\hline & 8 tahun & 21 & 85 \\
\hline & 9 tahun & 19 & 78 \\
\hline & 10 tahun & 16 & 79 \\
\hline & 11 tahun & 22 & 78 \\
\hline & 12 tahun & 15 & 76 \\
\hline \multirow{7}{*}{$\mathrm{P}$} & 6 tahun & 2 & 72 \\
\hline & 7 tahun & 18 & 74 \\
\hline & 8 tahun & 16 & 67 \\
\hline & 9 tahun & 19 & 74 \\
\hline & 10 tahun & 15 & 73 \\
\hline & 11 tahun & 11 & 81 \\
\hline & 12 tahun & 12 & 81 \\
\hline
\end{tabular}

Berdasarkan penjelasan tabel di atas harusnya usia adalah salah satu faktor yang dapat mempengaruhi nilai fungsi paru pada responden yang akan diteliti, dari nilai Prediksi Normal PEFR nilai fungsi paru anak laki-laki lebih besar dari pada nilai fungsi paru anak perempuan dan semakin usia responden bertambah dewasa maka nilai fungsinya semakin tinggi. Dari hasil penelitian ini didapatkan nilai fungsi paru anak laki-laki lebih tinggi dari nilai fungsi paru anak perempuan, akan tetapi jika dibandingkankan dengan usia semakin bertambahnya usia responden siswa laki-laki maupun siswa perempuan mengalami penurunan fungsi paru. Penurunan fungsi paru diduga oleh pencemaran udara yang terjadi di pabrik batu kapur sekitar sekolah.

Tabel 3. Perbandingan Nilai Fungsi Paru dengan Tinggi Badan

\begin{tabular}{ccc}
\hline & Laki-laki & \\
\hline tinggi badan $(\mathbf{c m})$ & frekuensi & nilai rata-rata \\
\hline $100-109$ & 2 & 113 \\
\hline $110-119$ & 23 & 95 \\
\hline $120-129$ & 35 & 83 \\
\hline $130-139$ & 41 & 77 \\
\hline $140-149$ & 12 & 69 \\
\hline $150-159$ & 5 & 70 \\
\hline $160-169$ & 1 & 78 \\
\hline & Perempuan & \\
\hline tinggi badan $(\mathbf{c m})$ & frekuensi & 77 \\
\hline $110-119$ & 20 & 71 \\
\hline $120-129$ & 28 & 72 \\
\hline $130-139$ & 21 & 73 \\
\hline $140-149$ & 20 &
\end{tabular}


Berdasarkan Tabel 3 dapat dilihat bahwa nilai fungsi paru pada anak harusnya dipengaruhi oleh tinggi badan. Karema tinggi badan adalah salah satu faktor yang dapat mempengaruhi nilai fungsi paru pada responden yang akan diteliti, dari nilai Prediksi Normal PEFR nilai fungsi paru anak laki-laki lebih besar dari pada nilai fungsi paru anak perempuan dan semakin tinggi responden maka nilai fungsinya semakin tinggi. Dari hasil penelitian ini didapatkan nilai fungsi paru anak laki-laki lebih tinggi dari nilai fungsi paru anak perempuan, akan tetapi jika dibandingkan dengan tinggi badan maka semakin bertambahnya usia responden siswa laki-laki dan siswa perempuan mengalami penurunan fungsi paru. Penurunan fungsi paru diduga oleh pencemaran udara yang terdapat di pabrik batu kapur sekitar.

Tabel 4. Perbandingan nilai fungsi paru dengan jenis kelamin

\begin{tabular}{ccc}
\hline $\begin{array}{c}\text { Jenis } \\
\text { Kelamin }\end{array}$ & Frekuensi & $\begin{array}{c}\text { nilai rata- } \\
\text { rata }\end{array}$ \\
\hline Perempuan & 93 & 75 \\
\hline Laki-laki & 119 & 83 \\
\hline
\end{tabular}

Berdasarkan tabel di atas dapat dilihat bahwa nilai fungsi paru dipengaruhi oleh jenis kelamin responden, nilai fungsi paru anak laki-laki lebih besar dari pada anak perempuan. Hal ini sesuai dengan nilai fungsi paru anak laki-laki dengan prediksi normal lebih besar dibandingkan dengan nilai prediksi normal anak perempuan.

Dari jumlah populasi 266 siswa, 119 responden adalah siswa laki-laki, 93 responden adalah siswa perempuan dan 14 siswa tidak masuk sekolah pada saat dilakukannnya penelitian. Jumlah siswa yang dilakukan pengukuran nilai fungsi parunya ada 212 siswa, hasil yang didapatkan $47 \%$ responden dengan kondisi paru normal yaitu 66 orang siswa laki-laki dan 34 orang siswa perempuan. Sedangkan 53\% kondisi di bawah kondisi normal yaitu 53 orang siswa laki-laki dan 59 orang siswa perempuan.

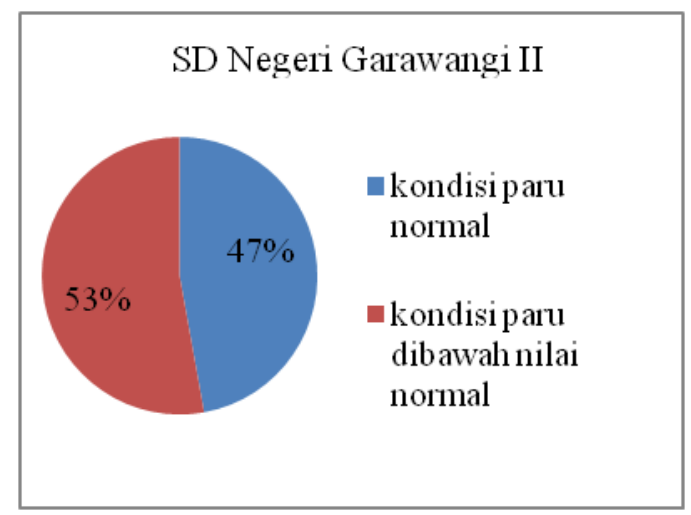

Gambar 2. Pesentase Kondisi Paru di SD

Negeri Garawangi II

Nilai prediksi normal paru setiap orang dipengaruhi oleh banyak faktor seperti jenis kelamin, tinggi badan, usia, ras, dan lain-lain. Dari hasil penelitian di sekolah SD Negeri Garawangi II dapat disimpulkan jika lingkungan di sekitar pabrik batu kapur dapat mengakibatkan kondisi paru seorang anak mengalami penurunan fungsinya.

Dapat dilihat bahwa potensi bahaya yang dapat ditimbulkan oleh lingkungan yang kualitas udaranya diduga buruk akan berdampak negatif bagi kesehatan paru-paru. Lingkungan dengan udara yang bersih sangat diperlukan untuk anakanak dengan masa pertumbuhan yang membutuhkan udara bersih dan kondisi lingkungan yang sehat. Apabila kualitas udara ambien di sekitar SD Negeri Garwangi II dan lokasi pabrik kapur yang diduga tercemar sudah berrangsur membaik maka akan meminimalisir potensi risiko yang dapat terjadi yaitu khususnya terhadap kesehatan paru anak disekitar lokasi pabrik tersebut.

\section{Kesimpulan}

Setelah dilakukannya penelitian dan pengolahan data dari SD Negeri Garawangi II yang berdekatan dengan lokasi pabrik batu kapur yang berlokasi di Desa Garawangi Kecamatan Sumberjaya Kabupaten Majalengka dapat disimpulkan sebagai berikut: 
1. Berdasarkan uji nilai fungsi paru yang dibandingkankan dengan usia, tinggi badan dan jenis kelamin. Hasil pengujian fungsi paru yang dibandingkan dengan usia dan tinggi badan mengalami penurunan fungsinya. Sedangkan yang dibandingkan dengan jenis kelamin nilai fungsi paru responden perempuan lebih rendah dari nilai fungsi responden laki-laki.

2. Dari penelitian uji fungsi paru di SD Negeri Garawangi II terdapat adanya penurunan nilai fungsi paru yang disebabkan penurunan kualitas udara disekitar lokasi penelitian yang di duga akibat adanya pabrik batu kapur, penelitian ini dilakukan dengan jumlah responden sebanyak 226 siswa dengan rincian 119 siswa laki-laki dan 93 siswa perempuan dan 14 siswa tidak masuk pada saat dilakukan penelitian di sekolah. Dengan jumlah siswa 212 orang yang dilakukan pengukuran uji fungsi paru didapatkan hasil $53 \%$ yaitu 112 orang siswa dari jumlah siswa mengalami penurunan fungsi paru dan
$47 \%$ yaitu sebnyak 100 orang siswa lainnya kondisi fungsi parunya normal.

\section{Daftar Pustaka}

Adeniyi, B. O., \& Erhabor, G. E. (2011). The peak flow meter and its use. African Journal of Respiratory Medicine , 5-8.

Idrus, S. W. (2013). Pencemaran Udara Akibat Pengolahan Batu Kapur di Dusun Open Desa Mangkung Praya Barat. J.Pijar MIPA, Vol. VIII No.2 : 85 - 90.

Rachmawati, S., M.Masykuri, \& Sunarto. (2013). Pengaruh Emisi Udara pada Sentra Pengolahan Batu Kapur terhadap Kapasitas Vital Paru Pekerja dan Masyarakat di Desa Karas Kecamatan Sedan Kabupaten Rembang. Jurnal Ilmu Lingkungan , 16-22.

Tim-Pneumobile-Project. (1992). Nilai Normal PEFR. Indonesia: Tim Pneumobile Project Indonesia. 